\title{
General surgery specialism in Turkey: Work power currently, continuity at quality and quantity
}

\author{
Ahmet Çınar Yastı ${ }^{1}$ (ID), Ahmet Deniz Uçar²(ID), Murat Kendirci ${ }^{3}$ (ID) \\ ${ }^{1}$ Health Sciences University, General Surgery, Ankara, Turkey \\ ${ }^{2}$ Bozyaka Education and Research Hospital, General Surgery, Izmir, Turkey \\ ${ }^{3}$ Hitit University, General Surgery, Corum, Turkey
}

\section{ABSTRACT}

Objective: As one of the oldest and main branches of medicine, process of General Surgery speciality training is long, expensive and difficult. Along with the principle of using limited sources wisely, there is a need for national forward planning in order to keep the number of General Surgery specialists in the proper level and in the proper quality. This study is made for the assurement of training quality specialists and for the sustainability in the best conditions after determining of the number of general surgeons, work force, and working conditions.

Material and Methods: The number of General Surgery specialists (professors, associate professors, specialists or General Surgery subspecialists) and assistants who actively work in our country from the end of 2017 in the public sector, private sector, and university hospitals, is examined. These numbers were subjected to cross evaluation according to the provinces, academic titles and number of assistants. The estimated ratio of the existing number of General Surgery specialists to upcoming five and ten years were calculated according to the data of Turkish Statistical Institute.

Results: From the end of 2017, 3957 General Surgery specialists are actively working in 1031 of 1499 health facilities. Four hundred and forty of them are titled as professors, 324 of them are titled as associate professors. For every 25 thousand people, there exist 1.22 surgeons. Ten years ago, this ratio was calculated as 1.27. The number of assistans, which was 1005 ten years ago, is decreased to 768 today, but the increase of the number of specialists is 409 .

Conclusion: The number of General Surgeons in our country is above the ideal ratio, which is one for 25 thousand people. In case rate of increase of the number of General Surgeons for the last 10 years continues, when the decrease of population growth rate is considered, there will be an uncontrolled increase in the number of surgeon per 25 thousand people. Just as the distribution of General Surgery specialists -whether or not having an academic title- is not balanced, the number of instructor per assistant is also excessive.

Keywords: Surgery, work power, quality, quantity

Cite this article as: Yastı AÇ, Uçar AD, Kendirci M. Genera surgery specialism in Turkey: Work power currently, continuity at quality and quantity. Turk J Surg 2020; 36 (1): 82-95

Corresponding Author

Ahmet Çınar Yastı

E-mail: cinaryasti@gmail.com

Received: 28.11 .2019

Accepted: 08.12.2019

Available Online Date: 03.01.2020

O Copyright 2020 by Turkish Surgical Society Available online at www.turkjsurg.com

DOI: $10.5578 /$ turkjsurg.4643

\section{INTRODUCTION}

One of the fundamental objectives of Turkish Surgical Association (TSA), as a professional body, is to advance the profession in every sense. Keeping the number of general surgery specialists at an ideal ratio is a parameter that could directly affect quality. Along with the studies carried out by TSA on general surgery manpower, the most extensive report on employment has been published by Terzi et al. using data from 2007 (1). As a result of the meetings with the Ministry of Health and Board of Specialty in Medicine held in light of this report, a decrease in the number of residents employed for general surgery specialty has been resorted.

There has been a worldwide debate ongoing for many years on whether the deficit in the number of surgeons, the irregularity of their distribution or both poses a problem. The basic reason for the debate is the fact that an agreement has still not been made on the number of general surgeons per population. To this end, a scientifically precise conclusion has not been reached despite the numerous studies conducted by various bodies and institutions, only recommendations have been put forth over general approval. In manifold studies from the USA, while one surgeon has been foreseen to a population of 25.000, a better performance has been claimed to be achieved with a surgeon/population ratio of 6/100.000, and $3 / 100.000$ has been defined as the critical value $(2,3)$. Giddings determined the ratio as 1/50.000 in a study conducted for England and Ireland in 1993 and noted that 
this ratio should be urgently lowered to the ratio of 1/30.000. In the upcoming years, studies from the UK reported a ratio between $1 / 20.000$ and $1 / 40.000$ (4).

Although surgeon per population is normal according to the population of the country, distribution irregularities constitute an issue in practice. While there can be more surgeons found in densely populated areas than needed, the number of surgeons found in rural areas is either below the number needed or even none $(3,5)$. This situation is similar in developed and developing countries $(1,5,6)$.

The discipline of general surgery is one of the specialties comprising the cornerstone of the healthcare system. In this sense, the surgeon pool must be constantly improved in quality and carefully planned in quantity. This study aimed at investigating the current status alongside the effect of 2007 data on 2017 and carrying out a prospective projection.

\section{MATERIAL and METHODS}

Approval was received from the Ethics Board of University of Health Sciences Izmir Bozyaka Education and Research Hospital. All healthcare institutions employing general surgery specialists all around Turkey were included into the study. Even though a number had not been given for Turkey in previous studies, a rate of one general surgery specialist per a population of 25.000 was accepted as a scale. Basic parameters supporting the specialist pool generating the general surgery workforce were thoroughly examined accepting as the number of physicians retiring from the profession and the number of those brought in the profession, in other words the number of residents being trained. General calculations and distributions were analyzed by determining cluster areas and those with deficits.

\section{RESULTS}

\section{Current Status in the General Surgery Residency Training Program in Turkey}

General surgery specialty has one of the longest professional training periods with a total of 11 years including 6 years of medical school and 5 years of residency. Following the 6-year medical school education, the candidates successful in the Examination for Specialty in Medicine held by Student Selection and Placement Center are placed into the specialties they have preferred. Those successful in this examination are trained in university hospitals or in states hospitals affiliated to universities. Training curriculum of general surgery in our country is prepared and determined by the Board of Specialty in Medicine. Resident Report Cards prepared accordingly are followed by the person in charge of training or by the head of the department of the relevant institution. Predicating on this report card including all necessary qualifications residents should be able to acquire during their training period, assessment and follow-up of their efficiency and competence in designated fields are ensured. Each specialist candidate is obliged to conduct a residency thesis at the end of the training period. The specialist candidate, whose thesis is found successful, is subject to a two-phase examination. First phase is a practical one where the candidate performs a surgery as the first surgeon under the supervision of a jury and replies to the questions asked. Oral examination evaluating their theoretical knowledge constitutes the second phase. The candidate found successful following this two-phase examination earns the right to receive the title of general surgery specialist.

Residency training is full of difficulties without a doubt. General surgery resident training in the world and in our country is bound to change, development and transformation in parallel to the developments in medicine (6). Due to the fact that it is not the main objective of this study and report, this important matter that should always be on the front burner will not be further scrutinized in this study.

Following the mandatory state service, the physician who has received the title'general surgery specialist' can work as a private senior physician, senior physician in state/private hospitals, or as a senior physician participating in academic career studies in training institutions of university/affiliated state hospitals.

\section{Institutions Giving Specialty Training in General Surgery}

General surgery specialty training de facto continues in a total of 93 inpatient healthcare facilities in our country. University hospitals comprise $51.7 \%$ of these units where residents are present and training still continues as of the time of the study (Table 1).

\section{Status of General Surgery Specialist Teachers}

Table 2 demonstrates the number of professors, associate professors and specialist physicians on the basis of provinces and

Table 1. The distribution of institutions providing specialty training (93) and the presence of teachers with academic titles

\begin{tabular}{|l|c|c|c|c|}
\hline Type of the institution offering training & Presence of academics & \multicolumn{2}{|c|}{ Total } \\
\hline Ministry of health & None & Present & 45 & $(48.4)$ \\
\hline University & 4 & 41 & 46 & $(49.5)$ \\
\hline Private institution & 0 & 46 & 2 & $(2.2)$ \\
\hline Total & 0 & 89 & 93 & $(100)$ \\
\hline
\end{tabular}


also the number of residents on the basis of provinces. While the total number of professors in Turkey was 440, the top three provinces were found respectively as Istanbul $(n=148)$, Ankara ( $n=$ $94)$ and Izmir $(n=22)$. These three provinces, with a total of 264 professors, contain $60 \%$ of the professors in Turkey. On the other hand, these three provinces only constitute 33\% of the country's population. There are no professors in 34 provinces and there is only one each in 10 .

The total number of associate professors in our country was found as 324 , and Istanbul $(n=89)$, Ankara $(n=71)$ and Izmir $(n=32)$ again comprise the top three provinces with the highest number of associate professors. While there are no associate professors in 38 provinces, there is only one each in 14 (Table 2). One hundred and twenty-one of the 237 surgeons with academic titles in Istanbul work for training clinics and 116 of them work for institutions that do not offer general surgery training. Overall in Turkey, a total of 221 surgeons with academic titles do not participate in training, and 175 (79.19\%) work for private institutions, 11 for hospitals of the Ministry of Health and 35 in private institutions that do not have any training programs. $52.4 \%$ of the surgeons $(116 / 221)$ that do not participate in training reside in Istanbul.

One professor and one associate professor are found in 6 provinces in our country. There are 20 residents in these 6 provinces in total and their distribution is as Van $(n=8)$, Batman $(n=0)$, Balikesir $(n=4)$, Kutahya $(n=4)$, Mugla $(n=3)$, and Amasya ( $n=$ 1). On the other hand, in 4 provinces with only one associate professor, there are three residents in total [Rize $(n=2)$, Erzincan $(\mathrm{n}=1)$ ] (Table 2).

When the number of specialists without any academic title is considered, these three provinces house 1223 specialists, and the ranking is as Istanbul $(n=772)$, Ankara $(n=258)$ and Izmir $(n=193)$. $38 \%$ of the general surgery specialist pool consisting 3193 specialists in Turkey are found in these three provinces comprising 33\% of the population. In other words, $62 \%$ of the general surgery specialists without any academic title serve $67 \%$ of the Turkish population. While there are no provinces without a general surgery specialist, this number is 9 and lower than 9 in 25 provinces (Table 2).

While total number of residents in Turkey is 768, 433 (56\%) of these are found in Istanbul $(n=223)$, Ankara $(n=149)$ and Izmir $(n=61)$, which make up of $33 \%$ of the population (Table 2).

When institutions with residents and those that provide residency training are scrutinized, it was seen that there were 4 surgical clinics without professors and associate professors. Moreover, it was also found that there were 5 surgical clinics without any professors that provided training with one associate professor (Table 2).

19.3\% of a total of 3957 general surgeons have academic titles with 440 professors and 324 associate professors. In a general overview, the rate of general surgery specialists with academic titles $(n=764)$ and general surgery residents $(n=768)$ is close to 1:1.

\section{General Surgery Specialist Pool in Turkey and Resident Support}

General surgery specialist pool: As of April 2017, there are health institutions with 1498 beds. Eight hundred and seventy-eight (58.6\%) of these are hospitals affiliated with the Ministry of Health and university hospitals constitute only $4.5 \%$ (Table 3).

The number of general surgery specialists in Turkey has been found as 3957 as of April 2017. General surgeons provide services in 1031 healthcare facilities in total, i.e. there is at least one general surgery specialist in 1031 healthcare facilities. Eight of the 467 hospital without a surgical specialist are university hospitals and these hospitals receive consultation services (Istanbul University Cardiology Institute, Ankara Baskent University Ayas Physical Therapy and Rehabilitation Center, Istanbul Medipol University Healthcare Training and Practice Center, Istanbul University Oncology Institute, Ankara Hacettepe University Medical School Ihsan Dogramaci Pediatric Hospital, Ankara Hacettepe University Medical School Oncology Hospital, Kars Kafkas University Healthcare Research and Practice Senter, Marmara University Neurologic Sciences Institute) (Table 4).

While 497 (48.2\%) of the 1031 hospitals where general surgeons work is affiliated with the Ministry of Health, the private sector constitutes $46 \%$ of the hospitals employing general surgery specialists with 474 hospitals. Besides, patients are treated in only 60 (5.8\%) university hospitals in the department of general surgery (Table 4).

Of the 3957 general surgery specialists employed in the indicated 1031 hospitals, 440 are professors and 324 are associate professors, and the number of actively working general surgery specialists without an academic title was found as 3193. A total of 2467 general surgery specialists are employed in institutions that do not offer training.

At the time of the study, a total of 938 hospitals that do not offer residency training but employ at least one general surgery specialist and 2467 general surgery specialists employed in these hospitals were probed into. Four hundred and seventy-two of the 938 healthcare facilities where service not training was taken as a basis belonged to the private sector and constituted 50.3\% of the facilities with bed in which surgeons provided treatment (Table 5). Table 5 shows the 14 (1.5\%) university hospitals that do not offer training but provide treatment.

In 120 of the 938 healthcare facilities that do not offer training, a total of 221 general surgeons with academic titles are employed and $83 \%$ of the 120 healthcare facilities comprise the private sector (Table 6). One hundred and twenty (15.7\%) of the existing 764 general surgeons with academic titles work in the private sector. While 543 of the existing 764 general surgeons with academic titles provide residency training de facto, 221 physicians work in institutions that do not provide training. While the rate 
Table 2. Provincial distribution of professors, associate professors and specialists and residents in general surgery specialty training program

\begin{tabular}{|c|c|c|c|c|c|}
\hline Province & Professor & Associate professor & Specialist & Resident & Total \\
\hline Adana & 15 & 15 & 92 & 24 & 122 \\
\hline Adiyaman & 0 & 0 & 17 & 1 & 17 \\
\hline Afyonkarahisar & 1 & 0 & 19 & 5 & 20 \\
\hline Agrı & 0 & 0 & 13 & 0 & 13 \\
\hline Amasya & 1 & 1 & 7 & 1 & 9 \\
\hline Ankara & 94 & 71 & 258 & 149 & 421 \\
\hline Antalya & 12 & 11 & 105 & 27 & 128 \\
\hline Artvin & 0 & 0 & 5 & 0 & 5 \\
\hline Aydin & 5 & 2 & 45 & 4 & 52 \\
\hline Balikesir & 1 & 1 & 44 & 4 & 46 \\
\hline Bilecik & 0 & 0 & 4 & 0 & 4 \\
\hline Bingol & 0 & 0 & 6 & 0 & 6 \\
\hline Bitlis & 0 & 0 & 8 & 0 & 8 \\
\hline Bolu & 2 & 2 & 18 & 5 & 22 \\
\hline Burdur & 0 & 0 & 9 & 0 & 9 \\
\hline Bursa & 10 & 3 & 119 & 18 & 132 \\
\hline Canakkale & 2 & 1 & 29 & 3 & 32 \\
\hline Cankiri & 0 & 0 & 4 & 0 & 4 \\
\hline Corum & 3 & 0 & 16 & 3 & 19 \\
\hline Denizli & 6 & 5 & 33 & 7 & 44 \\
\hline Diyarbakir & 5 & 7 & 37 & 11 & 49 \\
\hline Edirne & 2 & 5 & 20 & 12 & 27 \\
\hline Elazig & 4 & 5 & 23 & 8 & 8 \\
\hline Erzincan & 0 & 1 & 7 & 1 & 8 \\
\hline Erzurum & 4 & 2 & 20 & 10 & 26 \\
\hline Eskisehir & 6 & 0 & 45 & 8 & 51 \\
\hline Gaziantep & 7 & 4 & 58 & 11 & 69 \\
\hline Giresun & 0 & 2 & 13 & 0 & 15 \\
\hline Gumushane & 0 & 0 & 5 & 0 & 5 \\
\hline Hakkari & 0 & 0 & 8 & 0 & 8 \\
\hline Hatay & 2 & 5 & 54 & 5 & 61 \\
\hline Isparta & 3 & 0 & 21 & 10 & 24 \\
\hline Mersin & 5 & 4 & 63 & 6 & 72 \\
\hline Istanbul & 148 & 89 & 772 & 222 & 1009 \\
\hline Izmir & 22 & 32 & 193 & 61 & 247 \\
\hline Kars & 0 & 0 & 7 & 0 & 7 \\
\hline Kastamonu & 0 & 0 & 9 & 0 & 9 \\
\hline Kayseri & 5 & 1 & 51 & 17 & 57 \\
\hline Kirklareli & 0 & 1 & 16 & 0 & 17 \\
\hline Kirsehir & 2 & 0 & 12 & 1 & 14 \\
\hline Kocaeli & 10 & 4 & 83 & 13 & 97 \\
\hline Konya & 12 & 10 & 76 & 28 & 98 \\
\hline
\end{tabular}


Table 2. Provincial distribution of professors, associate professors and specialists and residents in general surgery specialty training program (continue)

\begin{tabular}{|c|c|c|c|c|c|}
\hline Province & Professor & Associate professor & Specialist & Resident & Total \\
\hline Kutahya & 1 & 1 & 21 & 4 & 23 \\
\hline Malatya & 7 & 7 & 35 & 13 & 49 \\
\hline Manisa & 5 & 3 & 54 & 5 & 62 \\
\hline Kahramanmaras & 1 & 2 & 39 & 5 & 42 \\
\hline Mardin & 0 & 0 & 17 & 0 & 17 \\
\hline Mugla & 1 & 1 & 49 & 3 & 51 \\
\hline Mus & 0 & 0 & 7 & 0 & 7 \\
\hline Nevsehir & 0 & 0 & 8 & 0 & 8 \\
\hline Nigde & 0 & 0 & 9 & 0 & 9 \\
\hline Ordu & 0 & 0 & 30 & 0 & 30 \\
\hline Rize & 0 & 1 & 11 & 2 & 12 \\
\hline Sakarya & 2 & 3 & 37 & 10 & 42 \\
\hline Samsun & 3 & 6 & 65 & 7 & 74 \\
\hline Siirt & 0 & 0 & 7 & 0 & 7 \\
\hline Sinop & 0 & 0 & 5 & 0 & 5 \\
\hline Sivas & 6 & 2 & 19 & 6 & 27 \\
\hline Tekirdag & 2 & 2 & 52 & 4 & 56 \\
\hline Tokat & 2 & 0 & 18 & 3 & 20 \\
\hline Trabzon & 7 & 5 & 28 & 10 & 40 \\
\hline Tunceli & 0 & 0 & 3 & 0 & 3 \\
\hline Sanliurfa & 1 & 0 & 42 & 3 & 43 \\
\hline Usak & 1 & 2 & 12 & 0 & 15 \\
\hline Van & 1 & 1 & 31 & 8 & 33 \\
\hline Yozgat & 2 & 0 & 9 & 2 & 11 \\
\hline Zonguldak & 4 & 1 & 16 & 5 & 21 \\
\hline Aksaray & 0 & 0 & 10 & 0 & 10 \\
\hline Bayburt & 0 & 0 & 2 & 0 & 2 \\
\hline Karaman & 0 & 0 & 8 & 0 & 8 \\
\hline Kirikkale & 2 & 1 & 7 & 3 & 10 \\
\hline Batman & 1 & 1 & 17 & 0 & 19 \\
\hline Sirnak & 0 & 0 & 10 & 0 & 10 \\
\hline Bartin & 0 & 0 & 4 & 0 & 4 \\
\hline Ardahan & 0 & 0 & 3 & 0 & 3 \\
\hline Igdir & 0 & 0 & 5 & 0 & 5 \\
\hline Yalova & 0 & 0 & 14 & 0 & 14 \\
\hline Karabuk & 2 & 0 & 11 & 0 & 13 \\
\hline Kilis & 0 & 0 & 5 & 0 & 5 \\
\hline Osmaniye & 0 & 1 & 19 & 0 & 20 \\
\hline Duzce & 0 & 0 & 10 & 0 & 10 \\
\hline Total & 440 & 324 & 3193 & 768 & 3931 \\
\hline
\end{tabular}


Table 3. Distribution of healthcare institutions with beds in Turkey

\begin{tabular}{|l|c|c|}
\hline Type of Institution & $\mathbf{n}$ & $\%$ \\
\hline Ministry of Health & 878 & 58.6 \\
\hline University & 68 & 4.5 \\
\hline Private institution & 552 & 36.8 \\
\hline Total & 1498 & 100 \\
\hline
\end{tabular}

Table 4. Distribution of healthcare institutions with beds that employ general surgery specialist

\begin{tabular}{|l|c|c|c|}
\hline \multirow{2}{*}{ Type of institution } & \multicolumn{2}{|c|}{ General surgeon presence } & Total \\
\hline Ministry of Health & None & Present & 878 \\
\hline University & 381 & 497 & 68 \\
\hline Private & 8 & 60 & 552 \\
\hline Total & 78 & 474 & 1498 \\
\hline
\end{tabular}

Table 5. Distribution of institutions with beds having a healthcare-service hospital objective that employ general surgery specialist but do not offer training

\begin{tabular}{|l|c|c|}
\hline Type of Institution & $\mathbf{n}$ & $\%$ \\
\hline Ministry of Health & 452 & 48.2 \\
\hline University & 14 & 1.5 \\
\hline Private & 472 & 50.3 \\
\hline Total & 938 & 100 \\
\hline
\end{tabular}

Table 6. Number of general surgeons with academic titles working in hospitals that do not offer training

\begin{tabular}{|l|c|c|c|}
\hline Type of institution & None & Present & Total \\
\hline Ministry of Health & 444 & $8(6.7 \%)$ & 452 \\
\hline University & 2 & $12(10 \%)$ & 14 \\
\hline Private & 372 & $100(83.3 \%)$ & 472 \\
\hline Total & 818 & $120(100 \%)$ & 938 \\
\hline
\end{tabular}

of surgeons with academic titles in 472 private institutions of the 938 service hospitals is $21.2 \%$ (100/472), this rate is $1.8 \%$ in hospitals affiliated with the Ministry of Health (8/452) and $85.7 \%$ in university hospitals (12/14).

General surgery specialty resident support: The vacancies opened for general surgery specialty between 2007-2017 in Turkey and the number of specialists given for these years were 1258 and 931, respectively. Three hundred and twenty-seven physicians completing their 6-year university education and then gaining the privilege to general surgery residency with the examination resigned from the general surgery department by not completing the residency. The commencement and completion rate of the general surgery training program was found as 74\%.

When the status of the residents receiving training at the present time is evaluated, there are a total of 768 residents, of whom
$433(56.38 \%)$ receive training in three provinces [Ankara ( $\mathrm{n}=$ 149), Istanbul ( $n=223$ ) and Izmir $(n=61)]$. In the evaluation of the number of teachers per residents, the rate was found as 5.0 in a private hospital where 5 teachers and one resident were employed during the collection of data; however, the resident was found to have left this institution during the research carried out for the interpretation of the data. This resident was excluded not to corrupt data soundness. Following this, 2 teachers per resident were found only in two healthcare institutions. These two institutions are Amasya University Sabuncuoglu Serefeddin Training and Research Hospital and Kirsehir Ahi Evran University Kirsehir Training and Research Hospital. It has been found as of the study date that there are no teachers in Adiyaman, Erzurum, Kocaeli and Mogadishu training clinics. A total of 543 physicians with academic titles provide training for 768 residents and the 
teacher per resident mean was found as 0.71(543/768) for Turkey. Following the omission of the general surgeons with academic careers employed in institutions that do not of fer training from the pool of 746 general surgeons with academic titles in Turkey, the number of teachers per resident was found as 119/149=0.798 for Ankara, 121/222=0.545 for Istanbul and $48 / 61=0.786$ for Izmir. The same number was found as $255 / 336=0.758$ for other provinces. Table 7 presents the number of residents under training according to years. In the last ten years, 2162 physicians have completed or are still continuing their residency training.

Besides the general surgery specialty, a central examination is performed for all specialties. Tables 8 and 9 show the preferences and scores related to these exam results. The fact that score averages of those placed in a specialty program but did not complete or even did not start the program are higher than those that started and continued a program is another important matter to be approached in a study.

\section{Changes in the General Surgery Specialist Pool on the Basis of Provinces}

As of April 2017, the number of specialists working de facto in Turkey is 3957. While the number of general surgery specialists in the last ten years increased by a number of 409 specialists, redundant physician number according to 1/25.000 rate was found as 725 (Table 10). The highest redundancy numbers of general surgeons were found in Istanbul and Ankara, and the highest vacancies were found in Sanliurfa and Diyarbakir, re- spectively (Table 10). As of 2017, surgeon rate for Turkey according to $1 / 25.000$ rate was found as 1.22/25.000. Regarding the ideal rate, there is still a 22\% surgeon redundancy in Turkey.

\section{DISCUSSION}

The history of surgical association in Turkey dates back to 1929 when the Turkish Surgical Society was founded. Following the 1980 military coup that shut down all associations, it was founded as the National Surgical Association in 1982 and named as Turkish Surgical Association in 1997. Since its establishment, studies in all related fields have been conducted for the improvement of surgery in every sense.

"Employment", which did not have any priority in the studies of the association due to lack of physicians nationwide in the past years, has become an important issue by putting forth the need to keep the pool of general surgeons in an appropriate balance with the newly founded educational institutions. This balance constitutes two major elements. The first is the ideal number of general surgeons for the country's population and the second is the provision of the appropriate distribution of the appropriate number of general surgeons regarding population according to the number of surgeons foreseen for unit population. In order to obtain all, it is mandatory to plan the number of surgeons retiring and the number of those joining the profession at a balance paying regard to the population of the country. Studies on general surgery manpower started with a report by Sayek at al. in 1990 (7). Afterwards, these studies continued with

Table 7. Number of residents accepted for residency training with the central examination according to years

\begin{tabular}{|l|c|c|c|c|c|c|c|c|c|c|c|}
\hline Years & $\mathbf{2 0 0 7}$ & $\mathbf{2 0 0 8}$ & $\mathbf{2 0 0 9}$ & $\mathbf{2 0 1 0}$ & $\mathbf{2 0 1 1}$ & $\mathbf{2 0 1 2}$ & $\mathbf{2 0 1 3}$ & $\mathbf{2 0 1 4}$ & $\mathbf{2 0 1 5}$ & $\mathbf{2 0 1 6}$ & $\mathbf{2 0 1 7}$ \\
\hline $\mathrm{n}$ & 256 & 312 & 288 & 106 & 133 & 163 & 147 & 139 & 196 & 200 & 222 \\
\hline
\end{tabular}

Table 8. Clinical score average according to the status of attendancy to residency training

\begin{tabular}{|l|c|c|c|c|}
\hline Status of residency & \multicolumn{2}{|c|}{ 2017 Spring } & \multicolumn{2}{c|}{ 2017 Fall } \\
\hline & Number of candidates & Average clinical score & Number of candidates & Average clinical score \\
\hline Continues residency training & 638 & 52.92 & 517 & 51.92 \\
\hline $\begin{array}{l}\text { Resigned while continuing } \\
\text { residency training }\end{array}$ & 163 & 53.62 & 77 & 52.33 \\
\hline $\begin{array}{l}\text { Had not started a program } \\
\text { though placed in a residency }\end{array}$ & 292 & 54.20 & 447 & 51.56 \\
\hline Total & 1093 & & 1041 & \\
\hline
\end{tabular}

Table 9. Resident vacancies opened for general surgery specialty in the Examination for Specialty in Medicine and the number of specialty physicians in the last ten years

\begin{tabular}{|l|c|c|c|c|c|c|c|c|c|c|c|c|}
\hline & $\mathbf{2 0 0 7}$ & $\mathbf{2 0 0 8}$ & $\mathbf{2 0 0 9}$ & $\mathbf{2 0 1 0}$ & $\mathbf{2 0 1 1}$ & $\mathbf{2 0 1 2}$ & $\mathbf{2 0 1 3}$ & $\mathbf{2 0 1 4}$ & $\mathbf{2 0 1 5}$ & $\mathbf{2 0 1 6}$ & $\mathbf{2 0 1 7}$ & Total \\
\hline Vacancies & 256 & 312 & 288 & 106 & 133 & 163 & 147 & 139 & 196 & 200 & 222 & 2162 \\
\hline Number of specialty physicians & 153 & 212 & 200 & 212 & 178 & 213 & 153 & 208 & 122 & 98 & 137 & 1733 \\
\hline
\end{tabular}


Table 10. Number of surgeons that should have been found in 2007 and 2007 according to provinces and the current number as of 2017 and rate of redundancy

\begin{tabular}{|c|c|c|c|c|c|c|c|}
\hline & & & A & B & $B-A$ & $\mathrm{C}$ & $C-B$ \\
\hline $\begin{array}{l}\text { Provinces } \\
\text { According to } \\
\text { licence plate }\end{array}$ & $\begin{array}{c}\text { Population } \\
2007\end{array}$ & $\begin{array}{l}\text { Population } \\
2017\end{array}$ & $\begin{array}{c}1 / 25.000 \\
2007\end{array}$ & $\begin{array}{c}1 / 25.000 \\
2017\end{array}$ & $\begin{array}{c}\text { 1/25.000 } \\
\text { Based } \\
\text { difference }\end{array}$ & $\begin{array}{c}\text { Current } \\
\text { surgeon } \\
\text { number } 2017\end{array}$ & $\begin{array}{c}\text { Redundancy } \\
2017\end{array}$ \\
\hline Adana & 2.006 .650 & 2.216 .475 & 80.3 & 88.7 & 8 & 122 & 33 \\
\hline Adiyaman & 582.762 & 615.076 & 23.3 & 24.6 & 1 & 17 & -8 \\
\hline Afyonkarahisar & 701.572 & 715.693 & 28.1 & 28.6 & 1 & 20 & -9 \\
\hline Agri & 530.879 & 536.285 & 21.2 & 21.5 & 0 & 13 & -8 \\
\hline Amasya & 328.674 & 329.888 & 13.1 & 13.2 & 0 & 9 & -4 \\
\hline Ankara & 4.466 .756 & 5.445 .026 & 178.7 & 217.8 & 39 & 423 & 205 \\
\hline Antalya & 1.789 .295 & 2.364 .396 & 71.6 & 94.6 & 23 & 128 & 33 \\
\hline Artvin & 168.092 & 166.143 & 6.7 & 6.6 & 0 & 5 & -2 \\
\hline Aydin & 946.971 & 1.080 .839 & 37.9 & 43.2 & 5 & 52 & 9 \\
\hline Balikesir & 1.118 .313 & 1.204 .824 & 44.7 & 48.2 & 3 & 46 & -2 \\
\hline Bilecik & 203.777 & 221.693 & 8.2 & 8.9 & 1 & 4 & -5 \\
\hline Bingol & 251.552 & 273.354 & 10.1 & 10.9 & 1 & 6 & -5 \\
\hline Bitlis & 327.886 & 341.474 & 13.1 & 13.7 & 1 & 8 & -6 \\
\hline Bolu & 270.417 & 303.184 & 10.8 & 12.1 & 1 & 22 & 10 \\
\hline Burdur & 251.181 & 264.779 & 10.0 & 10.6 & 1 & 9 & -2 \\
\hline Bursa & 2.439 .876 & 2.936 .803 & 97.6 & 117.5 & 20 & 132 & 15 \\
\hline Canakkale & 476.128 & 530.417 & 19.0 & 21.2 & 2 & 32 & 11 \\
\hline Cankiri & 174.012 & 186.074 & 7.0 & 7.4 & 0 & 4 & -3 \\
\hline Corum & 549.828 & 528.422 & 22.0 & 21.1 & -1 & 19 & -2 \\
\hline Denizli & 907.325 & 1.018 .735 & 36.3 & 40.7 & 4 & 44 & 3 \\
\hline Diyarbakir & 1.460 .714 & 1.699 .901 & 58.4 & 68.0 & 10 & 49 & -19 \\
\hline Edirne & 396.462 & 406.855 & 15.9 & 16.3 & 0 & 27 & 11 \\
\hline Elazig & 541.258 & 583.671 & 21.7 & 23.3 & 2 & 32 & 9 \\
\hline Erzincan & 213.538 & 231.511 & 8.5 & 9.3 & 1 & 8 & -1 \\
\hline Erzurum & 784.941 & 760.476 & 31.4 & 30.4 & -1 & 26 & -4 \\
\hline Eskisehir & 724.849 & 860.620 & 29.0 & 34.4 & 5 & 51 & 17 \\
\hline Gaziantep & 1.560 .023 & 2.005 .515 & 62.4 & 80.2 & 18 & 69 & -11 \\
\hline Giresun & 417.505 & 437.393 & 16.7 & 17.5 & 1 & 15 & -2 \\
\hline Gumushane & 130.825 & 170.173 & 5.2 & 6.8 & 2 & 5 & -2 \\
\hline Hakkari & 246.469 & 275.761 & 9.9 & 11.0 & 1 & 8 & -3 \\
\hline Hatay & 1.386 .224 & 1.575 .226 & 55.4 & 63.0 & 8 & 61 & -2 \\
\hline Isparta & 419.845 & 433.830 & 16.8 & 17.4 & 1 & 24 & 7 \\
\hline Mersin & 1.595 .938 & 1.793 .931 & 63.8 & 71.8 & 8 & 72 & 0 \\
\hline Istanbul & 12.573 .836 & 15.029 .231 & 503.0 & 601.2 & 98 & 1009 & 408 \\
\hline Izmir & 3.739 .353 & 4.279 .677 & 149.6 & 171.2 & 22 & 247 & 76 \\
\hline Kars & 312.205 & 287.654 & 12.5 & 11.5 & -1 & 7 & -5 \\
\hline Kastamonu & 360.366 & 372.373 & 14.4 & 14.9 & 0 & 9 & -6 \\
\hline Kayseri & 1.165 .088 & 1.376 .722 & 46.6 & 55.1 & 8 & 57 & 2 \\
\hline
\end{tabular}


Table 10. Number of surgeons that should have been found in 2007 and 2007 according to provinces and the current number as of 2017 and rate of redundancy (continue)

\begin{tabular}{|c|c|c|c|c|c|c|c|}
\hline & & & A & B & $B-A$ & $\mathrm{C}$ & $C-B$ \\
\hline $\begin{array}{l}\text { Provinces } \\
\text { According to } \\
\text { licence plate }\end{array}$ & $\begin{array}{l}\text { Population } \\
2007\end{array}$ & $\begin{array}{c}\text { Population } \\
2017\end{array}$ & $\begin{array}{c}1 / 25.000 \\
2007\end{array}$ & $\begin{array}{c}1 / 25.000 \\
2017\end{array}$ & $\begin{array}{c}1 / 25.000 \\
\text { Based } \\
\text { difference }\end{array}$ & $\begin{array}{c}\text { Current } \\
\text { surgeon } \\
\text { number } 2017\end{array}$ & $\begin{array}{c}\text { Redundancy } \\
2017\end{array}$ \\
\hline Kirklareli & 333.256 & 356.050 & 13.3 & 14.2 & 1 & 17 & 3 \\
\hline Kirsehir & 223.170 & 234.529 & 8.9 & 9.4 & 0 & 14 & 5 \\
\hline Kocaeli & 1.437 .926 & 1.883 .270 & 57.5 & 75.3 & 18 & 97 & 22 \\
\hline Konya & 1.959 .082 & 2.180 .149 & 78.4 & 87.2 & 9 & 98 & 11 \\
\hline Kutahya & 583.910 & 572.256 & 23.4 & 22.9 & 0 & 23 & 0 \\
\hline Malatya & 722.065 & 786.676 & 28.9 & 31.5 & 3 & 49 & 18 \\
\hline Manisa & 1.319 .920 & 1.413 .041 & 52.8 & 56.5 & 4 & 62 & 5 \\
\hline Kahramanmaras & 1.004 .414 & 1.127 .623 & 40.2 & 45.1 & 5 & 42 & -3 \\
\hline Mardin & 745.778 & 809.719 & 29.8 & 32.4 & 3 & 17 & -15 \\
\hline Mugla & 766.156 & 938.751 & 30.6 & 37.6 & 7 & 51 & 13 \\
\hline Mus & 405.509 & 404.544 & 16.2 & 16.2 & 0 & 7 & -9 \\
\hline Nevsehir & 280.058 & 292.365 & 11.2 & 11.7 & 0 & 8 & -4 \\
\hline Nigde & 331.677 & 352.727 & 13.3 & 14.1 & 1 & 9 & -5 \\
\hline Ordu & 715.409 & 742.341 & 28.6 & 29.7 & 1 & 30 & 0 \\
\hline Rize & 316.252 & 331.041 & 12.7 & 13.2 & 1 & 12 & -1 \\
\hline Sakarya & 835.222 & 990.214 & 33.4 & 39.6 & 6 & 42 & 2 \\
\hline Samsun & 1.228 .959 & 1.312 .990 & 49.2 & 52.5 & 3 & 74 & 21 \\
\hline Siirt & 291.528 & 324.394 & 11.7 & 13.0 & 1 & 7 & -6 \\
\hline Sinop & 198.412 & 207.427 & 7.9 & 8.3 & 0 & 5 & -3 \\
\hline Sivas & 638.464 & 621.301 & 25.5 & 24.9 & -1 & 27 & 2 \\
\hline Tekirdag & 728.396 & 1.005 .463 & 29.1 & 40.2 & 11 & 56 & 16 \\
\hline Tokat & 620.722 & 602.086 & 24.8 & 24.1 & -1 & 20 & -4 \\
\hline Trabzon & 740.569 & 786.326 & 2.6 & 31.5 & 2 & 40 & 9 \\
\hline Tunceli & 84.022 & 82.498 & 3.4 & 3.3 & 0 & 3 & 0 \\
\hline Sanliurfa & 1.523 .099 & 1.985 .753 & 60.9 & 79.4 & 19 & 43 & -36 \\
\hline Usak & 334.115 & 364.971 & 13.4 & 14.6 & 1 & 15 & 0 \\
\hline Van & 979.671 & 1.106 .891 & 39.2 & 44.3 & 5 & 33 & -11 \\
\hline Yozgat & 492.127 & 418.650 & 19.7 & 16.7 & -3 & 11 & -6 \\
\hline Zonguldak & 615.890 & 596.892 & 24.6 & 23.9 & -1 & 21 & -3 \\
\hline Aksaray & 366.109 & 402.404 & 14.6 & 16.1 & 1 & 10 & -6 \\
\hline Bayburt & 76.609 & 80.417 & 3.1 & 3.2 & 0 & 2 & -1 \\
\hline Karaman & 226.049 & 246.672 & 9.0 & 9.9 & 1 & 8 & -2 \\
\hline Kirikkale & 280.234 & 278.749 & 11.2 & 11.1 & 0 & 10 & -1 \\
\hline Batman & 472.487 & 585.252 & 18.9 & 23.4 & 5 & 19 & -4 \\
\hline Sirnak & 416.001 & 503.236 & 16.6 & 20.1 & 3 & 10 & -10 \\
\hline Bartin & 182.131 & 193.577 & 7.3 & 7.7 & 0 & 4 & -4 \\
\hline Ardahan & 112.721 & 97.096 & 4.5 & 3.9 & -1 & 3 & -1 \\
\hline Igdir & 181.866 & 194.775 & 7.3 & 7.8 & 1 & 5 & -3 \\
\hline
\end{tabular}


Table 10. Number of surgeons that should have been found in 2007 and 2007 according to provinces and the current number as of 2017 and rate of redundancy (continue)

\begin{tabular}{|c|c|c|c|c|c|c|c|}
\hline & & & A & B & $B-A$ & C & $C-B$ \\
\hline $\begin{array}{l}\text { Provinces } \\
\text { According to } \\
\text { licence plate }\end{array}$ & $\begin{array}{c}\text { Population } \\
2007\end{array}$ & $\begin{array}{c}\text { Population } \\
2017\end{array}$ & $\begin{array}{c}1 / 25.000 \\
2007\end{array}$ & $\begin{array}{c}1 / 25.000 \\
2017\end{array}$ & $\begin{array}{c}\text { 1/25.000 } \\
\text { Based } \\
\text { difference }\end{array}$ & $\begin{array}{c}\text { Current } \\
\text { surgeon } \\
\text { number } 2017\end{array}$ & $\begin{array}{c}\text { Redundancy } \\
2017\end{array}$ \\
\hline Yalova & 181.758 & 251.203 & 7.3 & 10.0 & 3 & 14 & 4 \\
\hline Karabuk & 218.463 & 244.453 & 8.7 & 9.8 & 1 & 13 & 3 \\
\hline Kilis & 118.457 & 136.319 & 4.7 & 5.5 & 1 & 5 & 0 \\
\hline Osmaniye & 452.880 & 527.724 & 18.1 & 21.1 & 3 & 20 & -1 \\
\hline Duzce & 323.328 & 377.610 & 12.9 & 15.1 & 2 & 10 & -5 \\
\hline Total & 70.586 .256 & 80.810 .525 & 2823.5 & 3232.4 & 409 & 3957 & 725 \\
\hline
\end{tabular}

A: 2007 need with 1/25.000 population rate, B: 2017 need with 1/25.000 rate, C: The current number of specialists as of 2017 in that province, C - B: The difference between the number of surgeons needed and the currently employed surgeons as of 2017.

those by Başkan and Terzi (1,8). A report prepared by 2007 data was published the very last (1). This study will be valuable for evaluating the studies conducted in 2007 and making predictions for subsequent years.

It is important in the planning of general surgery manpower that physicians graduating from medical school receive training in the field of general surgery. Along with replacing those that retire from the profession, meeting the surgeon need according to the increasing population is directly related to the number of physicians accepted for training. As of April 2017, residency training in general surgery is being given in a total of 93 healthcare facilities with beds in Turkey.

Beside $60 \%$ of all professors work in Istanbul, Ankara and Izmir and the rate of these provinces in the Turkish population is 33\%, it is significant that there are no professors in 34 provinces (41.9\%) of the 81 provinces and that there is only one professor in ten provinces. In the evaluation of associate professors, 59\% of the associate professors are found in these three provinces, there are no associate professors in 38 provinces and there is only one associate professor in 14 (17.3\%) provinces. 56.26\% (432/768) of the residents currently in training are found in these three provinces. Teacher rate per resident for these three provinces is 1.77 , which is more than twofold of the average in Turkey. However, the fact that general surgeons with academic titles do not work for training clinics prevent the rise to these rates. With the calculations made following the exclusion of the surgeons with academic titles that do not participate in training, Istanbul becomes prominent as the province where residency training is conducted with the least teachers, having received a score under the average of Turkey and the average of these three provinces.

In the 2004 study of our association, while there were 52 clinic chiefs, 255 professors, 76 associate professors, 76 assistant professors, 22 lecturers, 68 deputy chiefs, and 48 chief residents na- tionwide, the number of specialists without an academic title was given as 323 and the number of residents was found as 943 . The calculation performed using the data of the study revealed that the number of teachers per resident was 0.54 (510/943) (8). Only the numbers of three provinces were provided in the 2007 study. Professor and associate professor were not scrutinized for the training and research hospitals of these provinces and the number was given only for university hospitals. Again, since the number of residents was not given in the 2007 study, an assessment regarding the number of residents could not be performed (1). It was presented in the 2007 report that there were 182 professors, 53 associate professors, 27 assistant professors, 11 lecturers, 30 specialists, and 244 residents in Ankara, Istanbul and Izmir (1). While the number of professors of these three provinces increased 82, the number of associate professors increased 139.

Comparing the study by Baskan et al. in 2004, it can be seen that the number of teachers per residents has increased. However, it would be wrong to interpret and explain this picture with the increase in teachers. The report of Terzi and colleagues has put forth that there is no deficiency in the number of general surgery specialists in Turkey but there is a problem with their distribution (1). In order not to create an abundancy of general surgery specialists, meetings with the institutions indicated an arrangement that would decrease the number of general surgery residency positions in the Examination for Specialty in Medicine. In the end, the number of teachers per residents was positively increased by correcting two parameters.

This matter will not be thoroughly addressed since it is not the aim of the present study. However, matters like how many teachers should be present in a training institution and what should be done in the absence of a teacher must be investigated. Moreover, due to the fact that the aim of the present study is to assert the sufficiency of the number of general surgery specialists nationwide, to evaluate the reflection of the work carried out pursuant 
to the 2007 study and to present the distribution of specialists, matter of academics-teacher-the sufficiency of the training institution will not be discussed in this study.

$83 \%$ of the institutions where physicians with academic titles work is private ones. We are of the opinion that the physicians working in these private institutions prefer the private sector owing to the fact that working conditions are more appealing that those of the training institutions. The deterioration of both physical, legal and social conditions of the general surgeons incline them to work for private institutions. The same goes for many Western and Eastern countries, not just Turkey $(4,6,9,10)$. A similar situation like the shift to the private sector from academy is observed in the specialty preference of the physicians graduating from medical school $(11,12)$. The 2017 spring exam results of the Examination for Specialty in Medicine reveal that while 50\% of the candidates received 47 points and higher in Basic Medical Sciences Test (BMST), a 10\% fraction received 81.25 points and higher. In the Clinical Medical Sciences Test of the same examination, 50\% of the candidates scored 54 points and higher. This number indicates that clinical sciences are taught more commonly and the top $10 \%$ starts with a score of 75 and increases. In other words, $40 \%$ of the candidates succeeded with a score between $54-75$. Correct answer to 34 surgery related questions was 15.51 and was lower than internal medicine (21.91/40). The fact that 1093 candidates qualifying for clinical medical branches re-took the examination is of serious concern and scrutiny (Table 8 ). In the Spring 2017 examination, General Surgery was preferred by 114 physicians, the average score obtained was 52.53 and among 35 clinical specialties, General Surgery ranked the $30^{\text {th }}$ (11).

In the order of preference for the 2017 fall examination, general surgery was preferred by 113 physicians and ranked $29^{\text {th }}$ among 35 clinical specialties with an average score of 55.33 (12). In both periods, the number one medical branch preferred with the highest score average was Dermatological and Venereal Diseases $(11,12)$. Similar to other countries, the preferability priority of general surgery as a specialty regresses in Turkey. Along with the investigation of the reluctance of medical school graduates to general surgery, the reasons behind the physicians starting residency to leave the profession should also be examined (Table 9). Between 2007 and 2017327 physicians left without completing their residency training and the completion rate in reference to the vacancies opened was $74 \%$. The reasons for not completing the residency period and leaving the program for this $26 \%$ of the physicians must be reviewed, their rationale must be corrected and the profession should be made more appealing. Since there are no studies conducted on this matter, as a personal opinion, the authors of this article believe that economic and social conditions as well as the inappropriate working hours can be the reasons for leaving the program. Furthermore, another reason for the reluctancy towards general surgery may have its roots in the recently effectuated malpractice applications that do not have any grounded basis. Another matter to be kept in mind is the lack of concrete steps taken towards "violence against physicians", which leads to a decrease in the demand on the profession. Alarms are ringing for Turkey as regards general surgery since it ranked $29^{\text {th }}$ and $30^{\text {th }}$ among 35 specialties and physicians leave the residency period at a rate of $26 \%$. Following the completion of this article, significant studies will be commenced before the Ministry of Health and related institutions.

\section{General Surgery Specialist Pool in Turkey and Resident Support}

In the 2004 study of our association, the number of actively working specialists was not provided. In 2009, Terzi and colleagues reported 3594 actively working specialists nationwide.

As of April 2017, 58.6\% of the healthcare institutions with beds are affiliated with the Ministry of Health (Table 3). Practical problems occur when the Ministry of Health bothj determines policies in the health management of the country and turn it into service. When red tape is considered in the public offices despite valid reasons contained within, processes advance slowly and are delayed or even cancelled in many phases. Whereas, the private sector can act faster taking into account the profit/loss rate. Besides that, it is obvious that there are difficulties in public offices because of personnel regime and bureaucratic rules and practices in decision-making. It is known that the public office cannot do planning as easily as the private sector since civil servants have a responsibility of representing the state and the state has a responsibility of serving its citizens. In the meantime, as of April 2017, the number of general surgery specialists in Turkey is 3957 and the number of healthcare facilities giving service is 1031 .

More surgeons treat patients in more hospitals affiliated with the Ministry of Health. When the number of surgeries is added to the calculation, the sector that provides the most and the quality of the provided service will be revealed. For, the type of surgeries is as significant as the number of surgeries performed. A study investigating the type and number of surgeries performed by the general surgery clinics of healthcare institutions and training hospitals should be carried out with a thorough research.

The number of specialists without an academic title working in the designated 1031 hospitals was found as 3193. With the exclusion of the specialists working in training hospitals, 2467 general surgery specialists were found to be working in 938 healthcare institutions that act as a health-service hospital. $50.3 \%$ of these healthcare facilities whose essence is to serve are private institutions. In 120 of these 938 healthcare facilities that do not offer training employ general surgeons with academic titles, and 83\% $(100 / 120)$ of the health-service hospitals employing surgeons with academic titles belong to the private sector (Table 6). 28.93\% of the 764 general surgeons with academic titles work without 
contributing to the training of residents. The reasons behind the 175 surgeons with academic titles to work in the private sector should be investigated. It is a known fact that general surgery specialty necessitates going through a difficult training period and using public resources substantially. Training academics that would offer their expertise in training residents is a much longer, more troublesome and costly process. Even though it is not in the scope and aim of this study, the fact that $28.93 \%$ general surgery specialty teachers are actively working outside training institutions should be investigated for professional reasons. There is a need for serious and practical projects and applications to keep these teachers of outmost significance in universities or affiliated training hospitals.

When the status of the residents currently under training is assessed, there are 768 residents in total and of these, 430 (55.9\%) are located in Ankara ( $n=149)$, Istanbul $(n=222)$ and Izmir $(n=$ 61). The number of teachers per residents is $119 / 149=0.798$ for Ankara, $121 / 222=0.545$ for Istanbul and $48 / 61=0.786$ for Izmir. This number was found as $255 / 336=0.758$ for other provinces. Out of the 1258 medical school graduates accepted for training between 2007 and 2012, the number of those completing the training period and joining the pool of general surgeons between 2012 and 2017 was 931. Compared to the vacancies opened, $25.99 \%$ of the residents (327 residents) left the program. It is obvious that close evaluation of the working conditions and the status of the professionals actively engaged in the profession is highly effective in this situation. However, there is no study from our country regarding this issue. Studies from Taiwan to Ireland have indicated that there is a reluctancy towards not just general surgery but to other surgical departments as well $(6,10)$. As stated in the previous report, working conditions that are not meliorated, physical and psychological violence against physicians, unrighteous outcomes of the malpractice regulation that mostly aggrieves the physicians are unquestionably effective. A study scrutinizing this matter should be carried out urgently and necessary measures should be taken. Otherwise, general surgery will rank lower in the Examination for Specialty in Medicine and there may even be vacancies that are not selected $(11,12)$. In fact, the rate of dropping out of residency training, which is $25.99 \%$, appears as vacated placements (Table 9). The renouncement of placements decreases the success chance of further projections.

\section{Projection with 2007 Data and Its Comparison with 2017}

Terzi and colleagues emphasized in their study with 2007 data that there was no need of general surgeons in our country but the need to arrange their distribution was paramount. In the study, 1.27/25.000 surgeons were present in Turkey. A 2011 study conducted in the USA revealed that there were problems with both the number and the distribution of surgeons. For instance, in District of Colombia, there were 31.08 general surgeons per 100.000 population $(7.77 / 25.000)$ but in Nevada, this number was $6.55(1.63 / 25.000)$ (9). When the change in the rate of general surgeons per 100.000 population was evaluated on the basis of states, it was seen that the number of surgeons was diminished in all states except 7.

In a study investigating surgeon distributions, it has been reported that in comparison to family physicians, the distribution of general surgeons is more irregular (5).

"Critical" scarcity limit for the number of general surgeons has been reported in various studies as 0.75/25.000 and 1/25.000 is regarded as the minimum and $1.5 / 25.000$ is regarded as the ideal number of general surgeons $(3,13)$. When hospital service area is considered for the USA again, it is seen that $28 \%$ of the hospitals employ 0.75 or lesser general surgeons per 25.000 population.

There is not an exact rate for the United Kingdom. It was noted that the goal should be 1/30.000 when there was 1/50.000 surgeon before. When the targeted rate was exceeded due to the failure in planning, ideal number was set as 1/20.000 and a balance was tried to be accomplished (4). Despite this, the number and distribution of general surgeons is still problematic in England and Ireland (4).

The basic reason for the irregularity in the distribution of general surgeons in the USA is the malpractice suits executed without adequate descriptions and having uncontrolled sub-specialty. Wages policy has also been effective in this situation. A 10\% wage differential was brought to the surgeons in the USA; however, this policy which was put forth without considering the infrastructure and capabilities of the hospitals they worked in has brought along the fact that these surgeries with wage differential could not be performed in desired places (5). In short, unless social rights besides the environment and conditions are made more inviting, these places cannot be made appealing with financial support and these surgeons cannot be forced to operate in these places. Again in our country, the concept of "specialized surgeries" has been defined to increase the interest towards surgery and to make financial regulations and physicians performing these surgeries have been tried to gain the upper hand. These surgeries, for the general surgery specialty, have become lacking, insufficient in number and turned out to be surgeries that cannot be performed in many hospitals, just as the example seen in the USA. In short, we can see that there was no field success achieved with the scores of the Examination for Specialty in Medicine and with the presence of a $26 \%$ rate of drop out residents.

Besides, it has been noted that the work environment and work quality of the surgeons should be meliorated. General surgery planning should be made as a team. What is intended here is that there should be sufficient number of clinical allied health personnel and support personnel as well as surgical nurse, anesthesiologist and support personnel. Same-day surgery should be given special care and priority so that it can have a positive effect on patient cycle. Another point is made to the danger of 
sub-branching in our country. It is recommended that a single and corresponding data system be used by all state hospitals. The working hours, shifts and working conditions of general surgery specialists and residents must be improved.

Improvement can be seen in the number of shifts and working conditions for city hospitals taking into consideration the number of residents, and their results will be evaluated in the upcoming ten years.

In conclusion, the number of general surgeons and the rate of medical school graduates preferring general surgery are decreasing due to the indicated similar incorrect policies $(6,10)$. In our country, preference priority of general surgery in the Examination for Specialty in Medicine has unfortunately ranked lower in our country.

\section{The Effect of 2007 Projection on 2017}

It was clearly stated in 2007 that the number of general surgery specialists in our country was 1.27 per 25.000 population. Along with this number, it was also noted that there was a problem with the distribution of the surgeons and not with the quantity. It was reported that an arrangement in the distribution of the surgeons would compensate the relative deficiency in regions lacking surgeons. The population of Turkey rose 10.224.269 from 2007 and 2017. Parallel to this increase, the pool of general surgeons also increased by 363 persons. If it were ideal, 408 surgeons would be added to the pool based on the ideal rate of $1 / 25.000$. Whereas in reality, the general surgeon pool of Turkey was found as 1.27 per 25.000 in a calculation considering the number to be 1 surgeon per 25.000 population in 2007. While this number points that there are 1.27 surgeons per 25.000 population, as a result of the planning made and the diminished general surgery resident number, the number of general surgeons was decreased to 768 from 1005 but the ideal increase in the number of specialists was 363 not 408, the ideal quantity. In the end, general surgery specialist inflation was prevented by dropping the number to 1.22 from 1.27 and positive result was received for its improvement.

According to the data of the Turkish Statistical Institute, population growth rate continues with decreasing acceleration. According to calculations, the expected population for 2022 and 2027 is 83.540 .076 and 86.776 .550 , respectively. Reaching its highest limit in 2050 with a population of 93.475 .575 , the population is expected to decrease following this year (14). The number of surgeons per 25.000 with a total of 3957 surgeons is 1.22 . In the event of preserving the current number of residents and if the increase in the number of general surgeons supposedly stays the same (363 surgeons), it can be concluded that 4139 and 4320 surgeons will be achieved in 2022 and 2027, respectively, which means that there will be 1.2386 and 1.2445 surgeons per 25.000 in 2022 and 2027, respectively. It is concluded by preserving the current increase in the number of surgeons and the decrease in the population growth rate that the number of surgeons that showed a decrease in the past 10 years will go through a period of increase again. In this case, it is without doubt that a decrease in the number of residents is mandatory. Physician workload is excessive in General Surgery training clinics and reducing the number of residents may not be welcomed by the teachers in these clinics. The fact that city hospitals will bring the dispersed general surgery training clinics in big provinces and provide a more fruitful and efficient workforce can eliminate these concerns.

\section{CONCLUSION}

General surgery training is difficult, expensive and troublesome. Suitable teachers and persistence are mandatory in quality general surgery training. There is a need for urgent arrangements to ensure that teachers stay in training institutions. These urgent arrangements for Turkey are necessary due to the fact that significant number of teachers leave, residents in substantial numbers leave the training program and general surgery is among the least preferred specialties. Working conditions of the general surgeons must be improved, economic concerns must be eliminated and their lawful rights and protection must be provided. This is the best possible way to keep the general surgeon pool in balance both in number and in quality.

The results of this study will be shared with the Ministry of Health and other related institutions, and effort will be shown to make the necessary improvements.

\section{ACKNOWLEDGMENT}

The authors would like to thank Mr. Okan ERKMEN for his contribution in the interpretation of the numbers and to the projection.

Ethics Committee Approval: Approval was received from the Ethics Board of University of Health Sciences Izmir Bozyaka Education and Research Hospital.

Informed Consent: Not required in this study.

Peer-review: Externally peer-reviewed.

Author Contributions: Concept - A.Ç.Y; Design - A.D.U., M.K.; Supervision A.Ç.Y.; Resource - A.Ç.Y., A.D.U.; Materials - A.Ç.Y., A.D.U., M.K.; Data Collection and/or Processing - A.D.U., M.K.; Writing Manuscript - A.D.U., M.K.; Critical Reviews - A.Ç.Y.

Conflict of Interest: The authors have no conflicts of interest to declare.

Financial Disclosure: The authors declared that this study has received no financial support.

\section{REFERENCES}

1. Terzi C, Okman U, Eryılmaz M. Türkiye'de Genel Cerrahi Insan Gücü-iş Gücü ve Iş Yükü-Raporu. Publication of Turkish Surgical Society, 2009. [CrossRef]

2. PHYSICIAN-TO-POPULATION RATIOS (https://WwW.staffcare.com/ uploadedFiles/physician-to-population-ratios-physician-supplystandards.pdf, Acces Temmuz, 2018). [CrossRef]

3. Uribe-Leitz T, Esquivel MM, Garland NY, Staudenmayer KL, Spain DA, Weiser TG. Surgical deserts in California: an analysis of access to surgical care. J Surg Res 2018,223:102-8. [CrossRef] 
Giddings AE. Organization of general surgical services in Britain: strategic planning of workload and manpower. Working Party, Council of the Association of Surgeons of Great Britain and Ireland. Br J Surg 1993:80:1377-8. [CrossRef]

5. Neuwah/ S, Ricketts TC, Thompson K. Geographic distribution of general surgeons: comparisons across time and specialties. Bull Am Coll Surg 2011;96:38-41. (http://www.acshpri.org/documents/ACSHPRI_ FS8.pdf, Acces Temmuz, 2018). [CrossRef]

6. Chen YC, Shih CL, Wu CH, Chiu CH. Exploring factors that have caused a decrease in surgical manpower in Taiwan. Surg Innov 2014;21:520-7. [CrossRef]

7. Sayek I, Sayek F, Çakmakçı M, Çakmak N. Türkiye'de genel cerrahi insan gücü. Oral Presantation. Ulusal Cerrahi Kongresi Congress Book, 27-30 May 1990, Istanbul. [CrossRef]

8. Baskan S. Genel Cerrahi Uzmanlık Eğitimi Raporu 2003-2004. Publication of Turkish Surgical Society, 2004. [CrossRef]

9. The American College of Surgeons Health Policy Research Institute, Cecil G. Sheps Center for Health Services Research, University of North Caroline at Chapel Hill. http://www.acshpri.org/atlas/loadflash.php (Erişim Temmuz. 2018). [CrossRef]
10. Mealy K, Keane F, Kelly P, Kelliher G. What is the future for General Surgery in Model 3 Hospitals? Ir J Med Sci 2017;186:225-33. [CrossRef]

11. 2017 Tipta Uzmanlık Sinavi Ilkbahar Değerlendirme Raporu. OSYM, Değerlendirme Raporları Serisi No: 5, Mayıs 2018. (https://dokuman. osym.gov.tr/pdfdokuman/2018/GENEL/tusdegerlendirmeraporweb08052018.pdf, Acces Date Agustos, 2018). [CrossRef]

12. 2017 Tipta Uzmanlık Sınavı Sonbahar Değerlendirme Raporu. OSYM, Değerlendirme Raporları Serisi No: 7e, Haziran, 2018. (https://dokuman.osym.gov.tr/pdfdokuman/2018/GENEL/TUSSonbhrDegRaporweb06062018.pdf, Acces Date Agustos, 2018). [CrossRef]

13. Ricketts TC, Thompson K, Neuwah/ S, McGee V. Developing an index of surgical underservice. Bull Am Coll Surg 2011;96:45-7,57. (http:// www.acshpri.org/documents/ACSHPRI_FS7.pdf, Acces Temmuz 2018). [CrossRef]

14. TUiK verileri (http://www.tuik.gov.tr/PreHaberBultenleri.do?id=15844 Acces Eylul 2018). [CrossRef]

\title{
ORIJINAL ÇALIŞMA-ÖZET
}

Turk J Surg 2020; 36 (1): 82-95

\section{Türkiye'de Genel Cerrahi Uzmanlığı: İş Gücünde Güncel Durum, Nitelik ve Nicelikte Sürdürülebilirlik}

\author{
Ahmet Çınar Yastı ${ }^{1}$, Ahmet Deniz Uçar ${ }^{2}$, Murat Kendirci ${ }^{3}$ \\ 1 Sağlık Bilimleri Üniversitesi, Genel Cerrahi Anabilim Dalı, Ankara, Türkiye \\ ${ }^{2}$ Bozyaka Eğitim ve Araştırma Hastanesi, Genel Cerrahi Kliniği, Izmir, Türkiye \\ ${ }^{3}$ Hitit Üniversitesi Tıp Fakültesi, Genel Cerrahi Anabilim Dalı, Çorum, Türkiye
}

\section{ÖZET}

Giriş ve Amaç: Tıbbın en eski ve ana dallarından birisi olan Genel Cerrahi uzmanlığı eğitimi, uzun, pahalı ve zahmetli bir süreçtir. Kısıtlı kaynakların akılcı kullanımı ilkesi yanında bir meslek olarak Genel Cerrahinin uzmanı sayısının olması gereken seviyede ve kalitede tutulabilmesi için ileriye dönük ulusal planlamalara ihtiyaç vardır. Bu çalışma ülkemizdeki Genel Cerrah hekim iş gücü, sayısı, dağııımı ve çalışma koşullarının tespitini takiben kaliteli uzman yetiştirilmesi ve en iyi şartlarda sürdürülebilirliğinin temini için yapılmıştır.

Gereç ve Yöntem: Ülkemizde 2017 yılı sonu itibarı ile kamu, özel sektör ve üniversite tıp fakülteleri hastanelerinde faal olarak çalışan Genel Cerrahi uzmanı (profesör, doçent, uzman veya genel cerrahi yan dal uzmanı) ve asistan (araştırma görevlisi) sayıları irdelenmiştir. Bu sayılar illere, akademik unvanlara ve asistan sayılarına göre çapraz değerlendirmelere tabii tutulmuştur. Türkiye İstatistik Kurumu nüfus verilerine ve tahminlerine göre halihazırda Genel Cerrah sayılarının nüfusa oranları, önümüzdeki beş ve 10 yılda gerçekleşecek tahmini oranları hesaplanmıştır.

Bulgular: Ülkemizde 2017 yılı sonu itibarı ile 1499 sağlık tesisinin 1031'inde 3957 Genel Cerrahi uzmanı aktif çalışmaktadır. Bunların 440'ı profesör, 324'ü doçent unvanlıdır. Her 25 bin kişiye 1,22 cerrah düşmektedir. Bu oran 10 yıl önce 1,27 olarak bulunmuştu. On yıl önce 1005 olan asistan sayısının günümüzde 768'e düşmüş olmasına rağmen uzman sayısı 409 artış göstermiştir.

Sonuç: Ülkemizde Genel Cerrah sayısı ideal oran olan 25 bin kişiye bir sayısının üzerindedir. Nüfus artış hızındaki azalma dikkate alındığında, son 10 yıldaki Genel Cerrah artış hızının korunması durumunda 25 bin kişiye düşen cerrah sayısında kontrolsüz bir şekilde artış olacaktır. Ülkemizde akademik unvanlı olsun olmasın Genel Cerrahi uzmanı dağılımı dengeli olmadığı gibi asistan başına düşen eğitici sayısı da fazladır.

Anahtar Kelimeler: Genel cerrahi, iş gücü, kalite, kantite

Doi: 10.5578/turkjsurg.4643 